http://jurnal.fkip-uwgm.ac.id/index.php/Script

Script Journal: Journal of Linguistic and English Teaching

P-ISSN: 2477-1880; E-ISSN: 2502-6623

October 2017, Vol. 2 No. 2

\begin{tabular}{|c|c|c|}
\hline Received: & Accepted: & Published: \\
\hline \multicolumn{2}{|c|}{ Article DOI: http://dx.doi.org/10.24903/sj.v2i2.131 } \\
\hline
\end{tabular}

\title{
Cultural Values Integration in English Language Learning for Indonesian Young Learners
}

\author{
Nita Sari Narulita Dewi \\ Siliwangi University \\ nitasaridewi@yahoo.com
}

\begin{abstract}
This study investigates cultural values Integration in English language learning for primary school level. A case study is chosen to explore the phenomenon of what aspects reflecting cultural integration in English language learning classroom and its impact on the learners' language learning. Data are gathered through observation and interview. The acquired data are analyzed using Thematic Analysis by Braun and Clarke (2006). The study reveals that in L1 and L2 culture based materials are designed to be transferred in the process, mostly listening skill, vocabulary and grammar are presented by the learners, strategy of teaching and learning are performed by the teacher and learners, and cultural awareness and nationalism reflection show their identity as Indonesian young learners.
\end{abstract}

Keywords: Culture, English Language Learning, and Indonesian Young Learners 


\section{INTRODUCTION}

The study about correlation between culture and language has been a concern of L2 teachers and educators (BilalGenc and Erdogan Bada, 2005; Byram., 1997b; Kramsch, 2001). Buttjes (1990), by referring to some ethnographic language studies, summarizes several reasons why language and culture are from the start inseparably connected, i.e.: (1) language acquisition does not follow a universal sequence, but differs across cultures; (2) the process of becoming a competent member of society is realized through exchanges of language in particular social situations; (3) every society orchestrates the ways in which children participate in particular situations, and this, in turn, affects the form, the function, and the content of children's utterances; (4) caregivers' primary concern is not with grammatical input, but with the transmission of sociocultural knowledge; and (5) the native learner, in addition to language, acquires also the paralinguistic patterns and the kinesics of his or her culture (p. 55). So, it cannot be denied why Brown (1994) emphasizes, “... a language is a part of culture and a culture is a part of a language. (p. 164).

Researchers spend more discussion about the importance and possibilities of integrating culture to second language curriculum (Sysoyev \& Donelson, 2002). Bilal Genc and Erdogan Bada (2005) argued that teaching second language context without study of culture makes the instruction inaccurate and imperfect. The benefits can be acquired as the result of culture integration into language learning that studying culture gives students a reason to study the target language and the study culture increases learners' not only curiosity about and interest in target countries but also their motivation (Kitao, 2000). Studying culture plays role in general education, so the learners learn more about geography, history, etc. of the target culture (Cooke, 1970).

Furthermore, McKay, (2003) claims that culture influences language teaching in two ways, they are, linguistic and pedagogical. Linguistically, culture affects the semantic, pragmatic, and discourse level of the language. Meanwhile, pedagogically, culture influences the choice of the language material.

However Kitao (2000) remains, even though culture important and is included into language learning and teaching, some questions are still debatable in case of what should be taught and how culture could be taught most beneficially. In addition, issues issuing of decreased of nationalism faced by young Indonesian learners as the effect of learning new culture become the questioned idea to be discovered in the present research. 
Implementation of cultural values integration in English language learning for Indonesian young learners by one of English Course Institute in Ciamis Regency has attracted the researcher's attention to conduct a case study in exploring the phenomenon in terms of what aspects reflecting cultural integration in language learning and its impact to the learners' language learning. It is expected that this project contributes to answer what Kitao, (2000) remains above and discover whether learning new culture may decrease the culture of Indonesian-speaking young learners.

\section{METHODOLOGY}

A case study design is chosen by which the researcher is led to discover phenomenon existing in the English language learning classroom in primary school level in which culture is integrated in the instructional process. The design will discover what aspects reflecting cultural integration in language learning and its impact to the Indonesian young learners' English language learning.

Classroom observation was carried in six meetings to see the instructional process obviously reflecting culture integration in English language learning. Observation is focused on the process demonstrated by fifteen Indonesian young learners and one English teacher, materials, learning strategy, and other learning environment supporting the process. Through observation, the expected data, what aspects reflecting cultural integration in second language learning, can be acquired accurately.

Depth interview was conducted to three Indonesian young learners representing the group of participants to acquire data reflecting the impact of culture integration on their English language learning. Interview is conveyed in bahasa Indonesia as the participants are young learners with ages 10-12 years old and to make them freely answer the questions.

Data collected, then, are analyzed using thematic analysis byBraun and Clarke, (2006) to identify, analyze, and report the data. Consequently, the research starts from familiarizing with data, generating initial codes, searching for themes, reviewing themes, defining and naming themes, and producing the report.

\section{FINDINGS}

1. Instructional Material

Result of observation presents that instructional materials become the main idea of this English language learning process. The material is designed by the teacher which covers native and non-native culture of the Indonesian young learners. Some identified topics are found indicating the instructional material used in transferring knowledge to learners. For examples: Indonesia Islands, Inspiring Indonesian founding fathers, stories 
for kids (native and nonnative Indonesian-Speaking young learners, e.g. Cinderella, the prince and Frog, Sangkuriang, Malinkundang, etc ).

Using observation, it can be convinced the identified instructional materials were used in the process of instruction, as seen in the followings:

“Alright everyone, now we're studying about Indonesian Islands. Look at this picture, What Islands can you see? Alright Nadia, please...." (....Obs. /Meet. \#1)

“Ok, Dhiaz, Who is your favorite presidents of Indonesia?” (Obs. / Meet. \# 2)

“Which stories do you like, Cinderella or Sangkuring?" (Obs. /Meet. \#3)

Seeing the data, it can be assumed that in the process of instruction, the teacher has already designed the material in the form of printed paper or picture, video, and online material. Most authentic material is employed to transfer knowledge about Indonesia (knowledge of world) by which the learners are attracted to learn about geography of Indonesia, characteristic of people living in certain islands.

2. Strategy of teaching and learning

The result of observation also gives information about teaching strategy used in the process, such as story-telling, questioning-answering, games, coloring, reading poetry, and dramatization.

The followings are facts showing certain strategies performed in the process:

“Ok, everybody, I will give a nice story about The Princess and Frog. Everybody listen carefully,

Once upon a time, there lived a beautiful princess ......."

Why is the princess so sad? Does she cry? Who help her to get the ball from the pond?" Naraya, Please, read the story The Princess and Frog, and the other please listen carefully (obs./meet. \#4)

Salsa, one who drives a car, what is it? Delia, one who drives plane? Look at me, the plane is flying in the sky. (The teacher does the dramatization) (Obs. /Meet. \#5)

Nazwa, Color the picture one who teaches English in the class! Sofi, Color the picture one who help sick people. (Obs. /Meet. \#5) 
Naraya, I heard from your Mom, you like poetry, Can you read the poetry about MOM, please stand up. And then, you Dhiaz. Read this poetry about INDONESIA.

(Obs. /Meet. \#6)

Dealing with the foreign language teaching, then, the teacher chooses certain strategy to make the instruction effective. Mostly the teacher used storytelling and questioning answering towards the stories or other text given. The other strategy was the learners had to read a text loudly (e.g. reading stories) or to read poetry with dramatization. The students looked enthusiastic and actively learned and developed their communicative competence in the class. This condition can be supported or created since language learning strategies contribute to the development of the communicative competence of the students(Lessard-Clouston, 1997).

\section{Language Competence}

Interview is undertaken to the three participants in one meeting using Bahasa Indonesia. The following data, translated into English, shows that the learners get improved in the following particular areas:

a. Listening Skill

Seeing the data, it can be concluded that students get better listening skill because mostly the teacher uses storytelling, dramatization, pictures, and sometimes translation. Those strategies effectively make learners understand the material given. For example, the three respondents got interested and understood the story the Prince and Frog as the teacher used pictures and dramatization. In addition, mostly the teacher used English to make them used to listening English in the classroom and sometimes out of the class time.

The followings indicate the process stimulates their interest and improves their language competence, particularly on listening skill.

"I like the story because the teacher uses picture, so I can understand it. (Student\#2)

"Besides he uses picture when telling stories, he uses dramatization that make me fun and understand the story. (Students \#3) 
"I like the teacher because he mostly uses English to make me try to understand spoken English He, even, offers the drinks or meals using English and it challenges me to understand what he is saying." (Student \#1)

It is clear that language learners are capable of using a wide variety of language learning.

b. Vocabulary and Grammar

Integrating technology becomes the other strategy by the teacher to make the learners get involved actively and long span in their learning. When the learners were asked by the researcher what they were doing with the computer. They replied that they were studying vocabulary and grammar from the webs as instructed by the teacher.

"I learn words by matching game using computer, and it is interesting. (Student $\# 1$ and \#2)

"I love matching game using computer (web). The pictures are so colorful and help me to remember the material." (Students \#3)

When the learners were asked whether they loved learning English through computer, one of the students said, "I love English and I will use the web for learning English at home.” (Students \#2)

Referring the data, it cannot be denied that technology really helps the process successfully. Using webs, they learn English, particularly vocabulary and grammar independently monitored by the teacher.

\section{Cultural Awareness and Nationalism}

The result of interview also presents cultural awareness performed by three Indonesian young learners attending the English language learning classroom. Dealing with statements by Fishman (1985a) or Brown, (1994) that language and national identity or cultures are inseparable, evidently can be seen from the followings:

Once the process of instruction uses native and non-native culture, the learners are be able to compare and realize that every nation has its own culture or civilization which makes one country different from another ones. Indeed, the goal in culture teaching is to foster understanding, not necessarily love or affiliation (Brière,1986). 
When asked about the Indonesia islands the learners expressed, as follows:

"I should know Indonesia because it is my lovely country." (Student \#1)

"We have to know Indonesia islands because we are Indonesian citizen.” (Student \#3)

"If we know our country we can tell people, Indonesia is a beautiful country. Indonesia has many ethnics and natural resources" (Student \#2)

When asked about ASEAN countries, they are enthusiastically replied:

"I am proud of being Indonesian because it has many cultures." (Student \#1)

"Even though, Singapore is developed country, Indonesia is still number one in my heart.“(Student \#2)

“I love Indonesia. I want to build Indonesia because I was born in here.” (Student \#3)

The designed material is intended to have the learners experience with native and non-native culture, in turn, the learners understand the material contextually and reflect their own culture and appreciate the non-native one. This quite makes sense since the goal of the material is the learners know their own countries and, in turn, love their lovely country.

\section{DISCUSSION}

Based on the findings, there are 4 themes to discuss. They are Instructional Material, Strategy of teaching and learning, Language Competence, and Cultural Awareness and Nationalism.

1. Instructional Material

The material is designed by the teacher which covers native and non-native culture of the Indonesian young learners.Seeing the data, it can be assumed that in the process of instruction, the teacher has already designed the material in the form of printed paper or picture, video, and online material. Most authentic material is employed to transfer knowledge about Indonesia (knowledge of world) by which the learners are attracted to learn about geography of Indonesia, characteristic of people living in certain islands. In case of authentic language Widdowson (1998) stated that communicative approaches to language instruction must come to terms with the learners' reality and somehow create contextual conditions that are appropriate to them (p.712). Similarly, culture learning is most legitimately considered authentic when the realities of learners' identities are acknowledged in the classroom. (Knutson, 2006). 
2. Strategy of Teaching and Learning

Dealing with the foreign language teaching, then, the teacher chooses certain strategy to make the instruction effective. Mostly the teacher used storytelling and questioning answering towards the stories or other text given. The other strategy was the learners had to read a text loudly (e.g. reading stories) or to read poetry with dramatization. The students looked enthusiastic and actively learned and developed their communicative competence in the class. This condition can be supported or created since language learning strategies contribute to the development of the communicative competence of the students (Lessard-Clouston, 1997).

3. Language Competence

Referring the data, it cannot be denied that technology really helps the process successfully. Using webs, they learn English, particularly vocabulary and grammar independently monitored by the teacher. They feel technology (web) help their vocabulary and grammar better because Web based technology provides a wide range of e-learning experience (Ochoa \& Ramírez, 2016) by which the learners gain access to an unlimited source of authentic language for learning four skills of language (Ürün,2015). Technology enables students to access learning opportunities apart from the traditional barriers of time and place and lets students access learning opportunities outside of formal higher education institution (Office of Educational Technology,2017).

4. Cultural Awareness and Nationalism.

The designed material is intended to have the learners experience with native and non-native culture, in turn, the learners understand the material contextually and reflect their own culture and appreciate the non-native one. This quite makes sense since the goal of the material is the learners know their own countries and, in turn, love their lovely country. This is what is claimed by Fishman (1985a) that the connection between language and national identity is one which is very strong, sometimes inseparable. To deal with, the teacher designed material reflecting acquiring national identity through native-Indonesian speaking culture integration to language learning. In addition, the teacher designed non-native Indonesia young learners' culture to increase the learners' curiosity and interest in the target countries and motivation (Kitao, 2000). 


\section{CONCLUSION}

Obviously, cultural values integration into second language learning becomes prominent since the process promotes second language learners get motivated to have more second language learning experience. The present study reveals that L1 and L2 culture is important to be designed and transferred as instructional material to students. However, the teacher should also think the way of transferring the knowledge in creative way.

Pedagogically, the material designer or teachers are allowed to explore native and nonnative instructional material, at the same time the appropriate strategies should also be taken into consideration. Transferring knowledge becomes ineffective because misused of media or techniques employed do not contribute to the learners' language competence development. As the nurturing effect, it is quite possible, the material and strategy used affect to establish cultural awareness and nationalism of the learners reflecting their identity.

Thus, it can be inferred, cultural values integration into second language learning for primary school level contributes to English language competence achievement and establishes social competence of Indonesia young learners. 


\section{BIBLIOGRAPHY}

Braun, V., \& Clarke, V. (2006). Using Thematic Analysis in Psychology. Qualitative Research in Psychology, 3(2), 77-101.

Briere, J. F. (1986). Cultural understanding through cross-cultural analysis. The French Review, 60(2), 203-208.

Brown, H. D. (1994). Principles of Language Learning and Teaching (2nd. ed). New Jersey: Prentice-Hall, Inc.

Buttjes, D. (1990). Teaching Foreign Language and Culture: Social Impact and Political Significance. Language Learning Journal, 2(1), 53-57.

Cooke, M. A. (1970). Suggestions for Developing More Positive Attitude toward Native Speakers of Spanish. In Perspectives for Teachers of Latin American Culture (In H. N. S). Springfield, IL: State Department of Public Instruction.

Fishman, J. . (n.d.). Language, Ethnicity and Racism. In The Rise and Fall of the Ethnic Revival: Perspectives on Language and Ethnicity (In J.A. Fi, pp. 3-13). Berlin: Mouton Publishers.

Genc, B., \& Bada, E. (2005). Culture in Language Learning and Teaching. The Reading Matrix, 5(1).

Kitao, K. (1991). Teaching Culture in Foreign Language Instruction in the United States. Doshisha Studies in English, 52(53), 285-306. Retrieved from https://eric.ed.gov/?id=ED330214

Knutson, E. (2006). Cross-cultural Awareness for Second/Foreign Language Learners. Canadian Modern Language Review, 62(4), 591-610.

Kramsch, C. (2001). Language and Culture. Oxford: Oxford University Press.

Lessard-Clouston, M. (1997). Language Learning Strategies: An overview for L2 teachers. The Internet TESL Journal, 3(12), 69-80.

M., B. (n.d.). Cultural Studies and Foreign Language Teaching. In Bassnett, S. (ed.). In Studying British Cultures. An Introduction. (pp. 53-65). London: Rutledge.

McKay, S. L. (2003). The Cultural Basis of Teaching English as an International Language. Retrieved from http://virtualpostgrados.unisabana.edu.co/pluginfile.php/407997/mod_resource/content/2 /CTLL Text $1 \% 28$ McKay 2003\%29.pdf

Ochoa, M. A., \& Ramírez, M. S. (2016). Strategy based Instruction Facilitated by Technologies to Enhance Reading Comprehension. Journal of Language Teaching and Research, 7(4), 655-664. 
Script Journal: Journal of Linguistic and English Teaching, October 2017, Vol.2 No.2

Sysoyev, P. V., \& Donelson, L. R. (2002). Teaching Cultural Identity through Modern Language: Discourse as a Marker of an Individual's Cultural Identity. Journal of Eurasian Research, 2(4).

Technology, O. of E. (2017). Reimagining the Role of Technology in Higher Education. U.S. Department of Education.

Ürün, M. F. (2015). Integration of Technology into Language Teaching: A comparative review study. Journal of Language Teaching and Research, 7(1), 76-87. 